\title{
How Much Money Can an Equation Really Save? Standard Test Method for Calculating Cetane Index via Four Variable Equation
}

\author{
Chakra Bahadur Khadka, PhD
}

\begin{abstract}
The life of the people of a nation is not only affected by the availability and non-availability of petroleum product but also by the quality of the product made available. The purity and impurity of the available petroleum product impacts the physical health of people by affecting the environment in which they live in. To improve the testing procedures and enhance fuel quality standard, immediate attention should be paid to regulating some key parameters that are not in practice nowadays; in the measurement of PAH in diesel, only density and KV test is used in Nepal which is not sufficient methods to identify diesel adulteration. The Calculated Cetane Index by Four Variable Equation is not a discretionary method for articulating ASTM cetane number. Sample of diesel fuel were collected from different zone of Nepal and the collected sample were tested in the laboratory of Intermediate Technology Development Group, Nepal, Environment Assessment and Material Testing Division, Nepal, Nepal Bureau Standard and Metrology, Nepal Oil Corporation and produced the data of CI. The results show recovery at $10 \%, 50 \%$ and $90 \%$ volume at a given temperature. The calculation of minimum CI value is 32, then the recovery \% is at 170, 205 and 269 which indicates lower density type, e.g., kerosene is added in diesel fuel. Lower the CI, higher the strength of kerosene and vice versa. The result shows the cetane index of diesel fuel in Birgunj (BRJ) group is maximum 42, minimum 30 and average was 38. Whereas Raxual (RXL) delivered diesel has an average 48 cetane value. In the view of cetane value, average 10 cetane value is decreasing in diesel fuel in BRJ group sample. In the Kathmandu valley, results were maximum 43, minimum 32 and the average 38. Applying the law of altitude, the calculated value of cetane index strength is at an average of 34. The value of calculated cetane index is lower in the Kathmandu valley than RXL by 14 . This lower calculated value of cetane index indicates that there is about $50 \%$ adulteration in diesel fuel in Nepali fuel market. The equation is an accompanying tool for assessing cetane number when a result by Test Method D613 is not available and if cetane improver is not used. As a supplementary tool, the Calculated Cetane Index by Four Variable equation should be used with due regard for its limitations. Four-variable equation really saves the cost to calculate cetane index of diesel (ASTM D 4737). Therefore, the study recommends for the use of the equation rather than cetane engine to estimate to $C N$ for diesel supplied in Nepal.
\end{abstract}

Keywords: Cetane Index, Cetane Number, Four Variable Equation, Adulteration, Diesel.

1 Dr. Khadka is Faculty of Economics at Department of Economics, Patan Multiple Campus, Tribhuvan University, Nepal. 


\section{INTRODUCTION}

Petroleum product a non-renewable natural resource has a profound consequence in the functionality of the current economies. In the modern-day world, it has proved to be a lubricant to smoothen the wheel of economic activities. The activities relating to extraction of petroleum product and its refinement themselves are central to industrial activities which provide employment opportunities to the labor force of a country (Rom \& Hass, 1982; William, 1946; Hill, 2000; Mishra, Chawala, Srivastava \& Pachauri, 2005). The countries blessed with the natural endowment of petroleum resources have the potential of fueling their economies to grow within the domestic boundary and gain immensely by selling it to foreign countries. So, needless to say, the proper use of petroleum products has helped enhance human life and human civilization (NETL, 2008; Khadka, 2010). In one sense, it would not be wrong to say that modern economic development is strictly related to the right utilization of the petroleum (POL) product (Lal \& Clement, 2005). In the absence of the use of the POL it is hard to imagine the functioning of the modern world.

Economic and political activities are mutually interrelated to each other by means of production and supply management of the fuels like petrol, diesel and kerosene. The price of petroleum product and its quantity of production plays influential role in the economic and political aspects not only of Organization of the Petroleum Exporting Countries (OPEC) and but also in other countries that have an abundance of this natural resource. In Nepal petroleum product, has remained as the prime source of energy but it is entirely imported from outside. So, it has a deep impact on the economic and political life of the country. In different stages, the economy has experienced severe impacts resulting from the price change, particularly from the price rise, of the petroleum products. Price hike of POL product during 1970s affected not only Nepalese economic life but also the global economic arena. Moreover, a soaring price pattern of the petroleum product, particularly in the case of Nepal, is also caused by political intervention rather than the market realties till date (Khadka, 2010).

Measuring the Cetane Number $(\mathrm{CN})$ : Accurate measurements of the cetane number are rather difficult, as it requires burning the fuel in a rare diesel engine called a Cooperative Fuel Research (CFR) engine, under standard test conditions. The operator of the CFR engine uses a hand-wheel to increase the compression ratio (and therefore the peak pressure within the cylinder) of the engine until the time between fuel injection and ignition is $2.407 \mathrm{~ms}$. The resulting cetane number is then calculated by determining which mixture of cetane (hexadecane) and isocetane $(2,2,4,4,6,8$, 8-heptamethylnonane) will result in the same ignition delay (Joshua, Andre, \& Steven, 2009; Dooley et al., 2012). 
Ignition Quality Tester (IQT): Another reliable method of measuring the derived cetane number (DCN) of diesel fuel is the Ignition Quality Tester (IQT). This instrument applies a simpler, more robust approach to $\mathrm{CN}$ measurement than the CFR. Fuel is injected into a constant volume combustion chamber at approximately $575^{\circ} \mathrm{C}$ and 310 psi. The time between the start of injection and the recovery of the combustion chamber pressure to $310 \mathrm{psi}$ is defined as the ignition delay. This measured ignition delay is then used to calculate the DCN of the fuel. The fuel's DCN is then calculated using an empirical inverse relationship to ignition delay. Because of the reproducibility, material cost, and speed of the IQT, this has been the definitive source for DCN measurements of fuels since the late 2000s (Joshua, Andre, \& Steven, 2009 \& Dooley et al., 2012).

Fuel Ignition Tester: Another reliable method of measuring the derived cetane number of diesel fuel is the Fuel Ignition Tester (FIT). This instrument applies a simpler, more robust approach to cetane index $(\mathrm{CN})$ measurement than the CFR. Fuel is injected into a constant volume combustion chamber in which the ambient temperature is approximately $575^{\circ} \mathrm{C}$. The fuel combusts, and the high rate of pressure change within the chamber defines the start of combustion. The ignition delay of the fuel can then be calculated as the time difference between the start of fuel injection and the start of combustion. The fuel's derived cetane number can then be calculated using an empirical inverse relationship to ignition delay (Joshua, Andre, \& Steven, 2009; Dooley et al., 2012).

Cetane Index: Another method that fuel-users control quality is by using the $\mathrm{CI}$, which is a calculated number based on the density and distillation range of the fuel. There are various versions of this, depending on whether metric or imperial units are used, and how many distillation points are used. These days most oil companies use the '4-point method', American Society for Testing and Materials (ASTM), ASTM D4737, based on density, $10 \% 50 \%$ and $90 \%$ recovery temperatures. The '2-point method' is defined in ASTM D976, and uses just density and the 50\% recovery temperature. Diesel engine operation is primarily related to the actual cetane number and the cetane index is simply an estimation of the base cetane number (Joshua, Andre, \& Steven, 2009; Dooley et al., 2012).

The Scope of Cetane Index: According to National Fuel Quality Standards (NFQS), Australai in (2004), calculated cetane index equation which represents a means for directly estimatingthe ASTM Cetane number of distillate fuels from API gravity and mid-boiling point. The index value, as computed from the formula, is termed the CCI. This is a mathematical calculation method. It is a useful tool for estimating ASTM cetane number where a test engine is not available for determining this property. It may be conveniently employed for approximating cetane number where the quantity 
of sample is too small for an engine rating. The Federal Transportation Advisory Group (FTAG) number of the sample is entered into "fuel tests data base", the "cetane index" table and then the cetane index is automatically calculated using the $T_{50}$ from "Distillation Table" and the American petroleum Institute's (API) degrees from the "New Gravity" tablerevised a guidelineby United States Environmental Protection Agency Office of Transportation and Air Quality, in National Vehicle and Fuel Emission Laboratory in 2002.

Cetane number is determined by using a test engine. The cetane engines are more expensive and require more highly skilled operators than octane engines. They are not common and the cost of cetane engine is estimated more than $\$ 500,000$ in present cost. This machine is the gold standard for setting ratings. The wage of human resources, space for machine, quantity of fuel for operation engine, depreciation cost, cost of sound pollution and others are not included. For this reason, CI (which is an estimate to $\mathrm{CN}$ based on an empirical relationship between density and volatility parameters) is widely used for routine monitoring of diesel ignition quality (Taksande \& Hariharan, 2014).

To improve the testing procedures and enhance fuel quality standard, immediate attention should be paid to regulating some key parameters that are not in practice nowadays; in the measurement of PAH in diesel, only density and KV test is used in Nepal which is not sufficient methods to identify diesel adulteration. Four-variable equation for CI calculation is the really save the cost to diesel standard (ASTM D 4737). Therefore, the aim of this study is to explore how useful $\mathrm{CI}$ is as an estimate to $\mathrm{CN}$ for diesel quality standardized in Nepal and experiment the data for $\mathrm{CI}$ that how much money does the equation really save?

\section{REVIEW OF LITERATURE}

Fuel adulteration is a malpractice that can have serious economic and health related implications. In Nepal, the use of petroleum product on an average contributes near about 70 percent of the total fuel consumption and the consumption rate exhibits a growing trend of about 30 percent per year (Khadka, 2010). The government of Nepal has assigned Nepal Oil Corporation (NOC) with the responsibility of supply management of petroleum products in the country. The government established NOC in 1971 under Company Act 1965. It is a state-owned organization with natural monopoly on the supply and price management of petroleum product in the nation. The quantity, quality and price of the petroleum products are managed by it. Nepal government has also declared that in the near future it would invite the private sector to deal with petroleum business (Khadka, 2007; Khadka, 2010). 
Generally distinguished fuel categories are petrol, diesel, super kerosene oil, Jet-Al and a complex mixture of relatively volatile hydrocarbons which vary widely in their properties (Hill, 2000; Environment Australia, 2002). In the process of extraction and refinement petroleum products pass through different physical and chemical stages.

Consuming units have to choose quality fuels in order to preserve their machines, to get satisfactory performance of the engine, and to reduce negative effect on health. The quality of the fuel used determines the performance of the machine and the span of its usage as well. In Nepalese context, petrol, diesel and kerosene are imported from India in collaboration with Indian Oil Corporation (IOC). So, the responsibility of NOC is to preserve the quality of these fuel types imported from India and attention should be concentrated on ensuring the quality until it reaches the consumers (Khadka, 2010).

Many researchers have shown that fuel adulteration can increase the tailpipe emissions of hydrocarbons $(\mathrm{HC})$, carbon monoxide $(\mathrm{CO})$, nitrogen oxides $\left(\mathrm{NO}_{\mathrm{x}}\right)$, and particulate matter $(\mathrm{PM})$. Air toxin emissions of primary concern are benzene and polyaromatic hydrocarbons, both well-known carcinogens (Ken, Masami, \& Todd 2004). Benzene and polyaromatic hydrocarbon emissions depend mostly on fuel composition and catalyst performance. (World Bank, 1998, 2001, 2002a, 2003a; Environment Australia, 2002).These commercial abuses not only reduce consumer welfare and government excise revenue but the burning of imperfect fuels can also cause serious public health hazards and adulterated fuels may cause many other problems to the car engine, and it causes reduction in tax revenues of the government (World Bank,2002b, 2003b; Gupta, 2004; Gupta, 2005; Khadka, 2007; Giri, Murt, Adhikary \& Khanal, 2007; Romanini, Trindade \& Zanoni, 2009).

The petroleum products most frequently referred to any forensic science laboratories (FSL) for examination are petrol, kerosene, diesel, aviation turbine fuel/ kerosene -50 (ATF), lubricating oil, furnace oil, waste oil etc. These samples are forwarded to FSL for their purity, detection of adulteration if any or under the Essential Commodities Act 2000 and also under petroleum Act, illegal possession, breach of contract, cases etc. The analysis of these petroleum products is prima-facie, a complex task as these are complex mixtures of hydrocarbons obtained by fractional distillation of crude oil of variable nature, yet broadly falling in well recognizable boiling/distillation ranges and having other physical-chemical parameters, for instance, as laid down by the government of Nepal standard specification for petrol (IS 2796/2000) which includes among other parameters, the distillation recovery criteria which is very helpful in assessing these samples, notwithstanding the fact that the final boiling point (FBP) max: $215^{\circ} \mathrm{C}$ as prescribed therein appears to be relaxed too much on the higher side. The density at $15^{\circ} \mathrm{C}$ in $\mathrm{kg} / \mathrm{m}^{3}$ is $710-770$ which is very wide range and allows 
normally 40 - 50\% adulteration using any solvent or middle distillate etc. The situation is, unfortunately, not the same as in the case of kerosene and diesel which may also be termed as middle distillates. As stated therein, these specifications kerosene IS (1459/1974 reaffirmed in 1991 and diesel IS 1460/2000) are formulated by keeping in view the difficulties in importing the crude oil and also with a view to increase the availability of middle distillate as much as possible (Khadka, 2010).

The urban air pollution primarily arising from the use of adulterated petroleum products in the world in general and in the context, of least developed countries like Nepal in particular has become a serious problem (ITDG, 2002; Ale, 2003). The air pollution in urban areas like Kathmandu is chiefly attributed to the tailpipe emission from vehicles (Ale, 2003; Daniel, 2003). Although at the very initial stage the effects on human health arising from the contaminated environment due to fuel adulteration are not easily perceivable enough, it has serious effect on human beings in the long-run.

There is now serious concern about the rapidly increasing number of petrol and diesel vehicles and the deteriorating quality of these fuels due to deliberate adulteration of fuel (Taksande \& Hariharan, 2014). The constantly rising number of these vehicles in cities contributes significantly, increasing the degree of air pollution (ITDG, 2002). And it is rightly said that governments of the poor and developing countries are made to run budget deficits year after year on energy importation while their citizens are engaged in an impudent business of fuel adulteration (Khadka, 2010).

No serious research has been done to verify whether the kerosene, petrol, and diesel imported from Indian sources reach the doorsteps of the final users in the same degree of purity or not. This is probably the first ever effort devoted to address the issue. In particular, the main research questions of this study are: Many developing countries are trying to clean up air pollution by setting tighter standards for transport fuel. But these standards are often abused through such practices as fuel adulteration, mislabeling, and smuggling (Masami, 2003, Gupta, 2004; Gupta, 2005; ESPAM, 2002). Other forms of abuse such as short selling and tax evasion make unfair competition and degrade fuel markets further. The principal fuel for the road transport sector is petrol for spark ignition engines and diesel for compression ignition engines.

According to Dooley et al. (2012) Cetane is the chemical compound with chemical formula n-C16H34, today named hexadecane according to International Union of Pure and Applied Chemistry (IUPAC) rules. It is an unbranched alkane, a saturated hydrocarbon chain with no cycles. Cetane ignites very easily under compression, so it was assigned a cetane number of 100, while alpha-methyl naphthalene was assigned a cetane number of 0 . All other hydrocarbons in diesel fuel 
are indexed to cetane as to how well they ignite under compression. The cetane number therefore measures how quickly the fuel starts to burn (auto-ignites) under diesel engine conditions. Since there are hundreds of components in diesel fuel, with each having a different cetane quality, the overall cetane number of the diesel is the average cetane quality of all the components (Helga \& Paulo, 2012).

\section{DATA AND METHODOLOGY}

\section{Sources of Data}

The secondary data were collected from Indian Oil Corporation (IOC) Raxual Depot (RXL) of quality certificate data covering with $\mathrm{CI}$, kinematic viscosity (KV), density and temperature of different time period. The data of Density, $\mathrm{KV}, \mathrm{T}_{10^{\prime}}, \mathrm{T}_{50^{\prime}} \mathrm{T}_{90}$ were produced their laboratory test by Intermediate Technological Development Group (ITDG), Environmental Assessment and Material Testing Division (EAMTD), Nepal Bureau of Standards \& Metrology (NBMS), and Nepal Oil Corporation (NOC).

\section{Four-Variable Equation}

It is an indicative of ignition quality and can be calculated from density and distillation data. One of the very popular techniques is ASTM D 86 which further uses ASTM D 4737-09(2009). Under this method, a correlation in SI units is established between the ASTM cetane number and density at $10 \%, 50 \%$ and $90 \%$ recovery temperatures of the fuel. The relationship is given by the following four-variable equation:

$\mathrm{CCI}=45.2+(0.0892)\left(\mathrm{T}_{10 \mathrm{~N}}\right)+(0.131+(0.901)(\mathrm{B}))\left(\mathrm{T}_{50 \mathrm{~N}}\right)+$

$(0.0523-(0.420)(\mathrm{B}))\left(\mathrm{T}_{90 \mathrm{~N}}\right)+(0.00049)\left(\left(\mathrm{T}_{10 \mathrm{~N}}\right)^{2}-\left(\mathrm{T}_{90 \mathrm{~N}}\right)^{2}\right)+(107)(\mathrm{B})+(60)(\mathrm{B})^{2}$

Where:

$\mathrm{CCI}=$ Calculated Cetane Index by use of four variable equation,

D = Density at $15^{\circ}$ C, determined test method D 1298 ,

$\mathrm{DN}=\mathrm{D}-0.85$,

$B=\left(\mathrm{e}^{(-3.5)(\mathrm{DN})}\right)-1$,

$\mathrm{T}_{10}=10 \%$ recovery temperature, ${ }^{\circ} \mathrm{C}$, determined by test method $\mathrm{D} 86$ and corrected to standard barometric pressure, 
$\mathrm{T}_{10 \mathrm{~N}}=\mathrm{T}_{10}-215$,

$\mathrm{T}_{50}=50 \%$ recovery temperature, ${ }^{\circ} \mathrm{C}$, determined by test method 86 and corrected to standard barometric pressure,

$\mathrm{T}_{50 \mathrm{~N}}=\mathrm{T}_{50}-260$,

$\mathrm{T}_{90}=90 \%$ recovery temperature, ${ }^{\circ} \mathrm{C}$, determined by test method 86 and corrected to standard barometric pressure,

$\mathrm{T}_{90 \mathrm{~N}}=\mathrm{T}_{90}-310$,

The alternate formula for the calculation of Cetane Index as per ASTM D976-91 is given in the following equation

$\mathrm{CCI}=454.74-1641.416 \mathrm{D}+774.74 \mathrm{D}^{2}-0.554 \mathrm{~B}+97.803(\mathrm{Log})^{2}$

Where $\mathrm{D}=$ Density at $15^{\circ} \mathrm{C} \mathrm{g} / \mathrm{ml}$ and $\mathrm{B}=$ mid - boiling temperature ${ }^{\circ} \mathrm{C}$

\section{RESULT AND DISCUSSION}

To identify the diesel fuel adulteration, density and kinematic viscosity (KV) parameters are generally practiced in Nepal. The NS specification of diesel oil is also the same as IS specification but there is one difference between IS and NS specification, that in Indian Oil Corporation tests fuel after refinery where it is checked whether the specification meets or not for any batch product of that batch number and the value of parameters is specified. NS also follows the same rule but Nepal is a consumer country. In this manner, the batch product of specified value strengthens the NS specification.

\section{Cetane Index Calculation of Diesel Fuel}

The fuel sample of diesel were collected and tested in laboratory to identify the cetane index (CI). The cetane index was tested and calculated for the first time in Nepal in 2002 research consultant of this author for ITDG laboratory and was transmitted for conformity test for inter laboratory variation to NBMS, NOC and EAMTD laboratories. The result found that was in balance between the laboratories or there was no variation between test results. Given figure of $\mathrm{RXL}$, the $\mathrm{CI}$ is distributed in 49 to 54 areas but all samples of Birgunj (BRJ) group are plotted 42 and below. The result of diesel sample does not fulfill the requirement lab parameters with RXL. The result in diagrammatic form is shown in Figure 1. 
Graph of Cetane Index BRJ PP Against Cetane Index IOC RXL

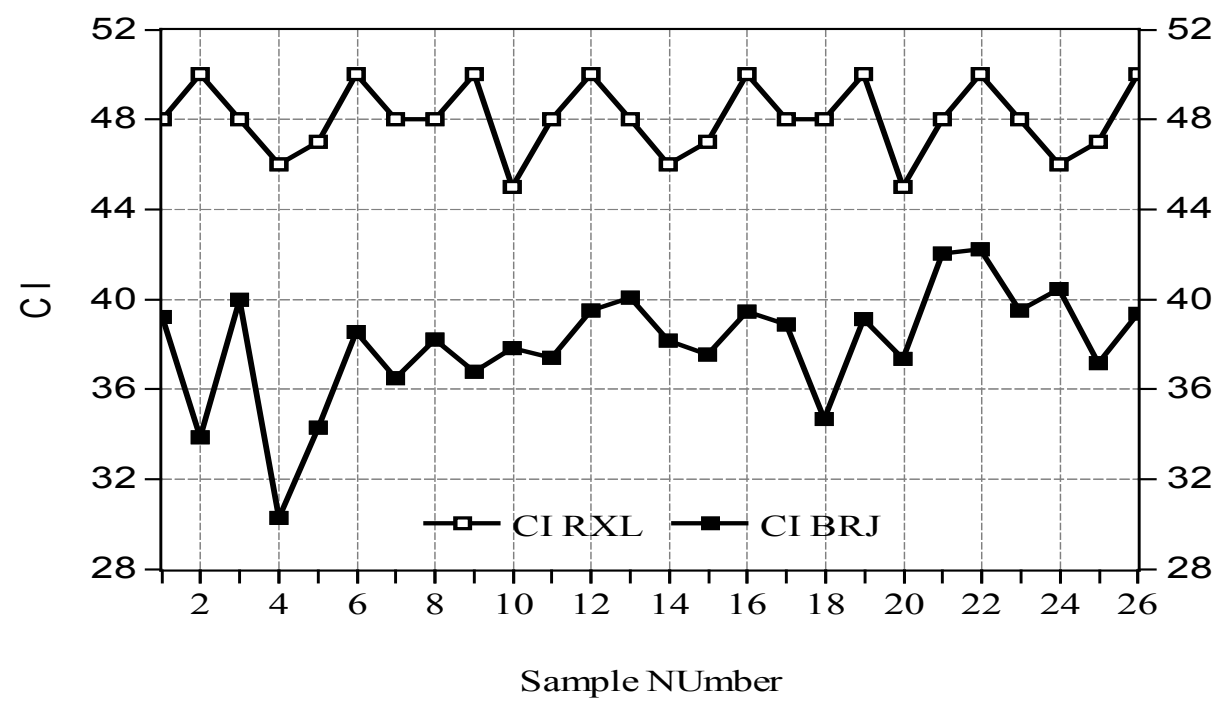

Figure 1: CI Calculated from Collected Sample from BRJ PP with RXL IOC

The distribution of CI samples in Kathmandu valley was also found below 42 which are lower than BRJ group due to altitude law. The results conclude that Kathmandu is the higher diesel adulteration zone. A correlation in CI units has been established between the ASTM cetane number and density and 10\%, 50\% and $90 \%$ recovery temperatures of the fuel.

The higher the cetane number, the shorter the delay between injection and better is the ignition quality and vice versa. The cetane number of a fuel is determined by comparing its ignition quality under standard operating conditions with a blend of two reference fuels- the straight chain-paraffin n-cetane, which ignites very quickly, and branched paraffin, heptamethylnonane, which has a long ignition delay. Cetane number is determined by the composition of the diesel fuel. Research has shown that higher-cetane fuel is associated with improved combustion, improved cold starting reduced white smoke, less noise, and reduced $\mathrm{HC}, \mathrm{CO}$, and particulate emissions particularly during the vehicle warm-up phase(Cataluna \& Silva, 2012). The time to start, achieve a stable idle and the time to reach 50 percent of the initial smoke level all increase progressively with decreasing cetane number. The result relating to Kathmandu Valley test is given in Figure 2. 


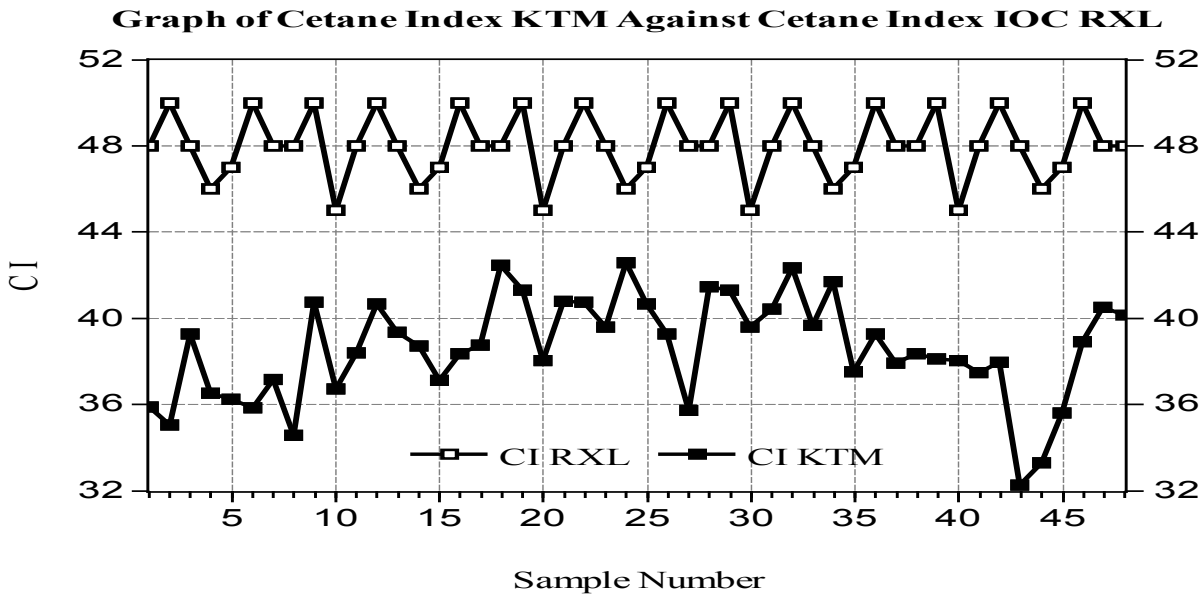

Figure 2: Calculated CI in Kathmandu Valley with Mother Sample

Some black and gaseous emissions increase with lower cetane fuels, especially at cetane levels below 45. Variations in cetane number have a less pronounced effect on passenger car emissions compared to heavy-duty truck emissions. The laboratory test results show recovery at $10 \%, 50 \%$ and $90 \%$ volume at a given temperature. If the value of cetane index is 48 or 52, recovery percentage also changes which is given in table number 10 as 219, 320, 366 and 205, 305, 364. The findings of laboratory show minimum CI value is 32, then the recovery \% is at 170, 205 and 269 which indicates lower density type; e.g. kerosene is added in diesel fuel. Lower the CI, higher the strength of kerosene and vice versa. The result shows the cetane index of diesel fuel in BRJ group is maximum 42.24, minimum 30.25 and average 38.01 whereas RXL delivered diesel had an average 48 cetane value. In the view of cetane value, average 10 cetane value is decreasing in diesel fuel in BRJ group sample.

In the Kathmandu valley, the laboratory results were maximum 42.56, minimum 32.26 and the average 38.38. Applying the law of altitude, the calculated value of cetane index strength is at an average of 34. The value of calculated cetane index is lower in the Kathmandu valley than RXL by 14 . This lower calculated value of cetane index indicates that there is about $50 \%$ adulteration in diesel fuel in Nepali fuel market. If kerosene and lubricant are mixed in diesel oil the distillation curve changes from the original level. $\mathrm{T}_{10^{\prime}} \mathrm{T}_{50}$ and $\mathrm{T}_{90}$ are the important values of distillation which can be calculated by the CI value of tested sample; this is also important to identify diesel adulteration and verify with the original CI value. 
There is a greater scope of cetane index; the formula represents a means for directly estimating the ASTM cetane number of distillate fuels from API gravity and mid-boiling point. The index value, as computed from the formula, is termed as the calculated CI. This is a mathematical calculation method. The significant calculated cetane index is a useful tool for estimating ASTM cetane number where a test engine is not available for determining this property. It may be conveniently employed for approximating cetane number where the quantity of sample is too small for an engine rating. The sample is entered into "fuel tests data base", the "cetane index" table and then the cetane index is automatically calculated using the $\mathrm{T}_{50}$ from "distillation table" and the API degrees from the "new gravity" table. CI is most likely to balance costs and benefits, provided sufficient samples are tested to provide a statistically valid result.

\section{CONCLUSION}

The synchronous fluorescence method can be effectively used to identify contaminants in petroleum samples under conditions of local calibration. A calibration graph has been constructed for synthetic adulterant mixtures (obtained by mixing pure kerosene with pure petrol). This calibration graph, obtained from the synchronous fluorescence method, is highly effective in the whole range of $1 \%$ to $90 \%$ volume of kerosene. This directly gives an estimate of the amount of kerosene present in the commercial samples. The method is simple, reliable, and gives advantages in terms of both sensitivity ( $1 \%$ volume) and accuracy compared with any other method. Calculated cetane index and synchronous fluorescence method can help to identify all possible sources of diesel adulteration. The method is cost effective in developing countries like Nepal and it helps reduce diesel adulteration. Reduce of adulteration increase vehicle mileage and increasing consumer welfare, reduce replacement investment on vehicle.

Continuing the test of kinematic viscosity, density test and opacity value are useful parameters for testing adulteration of diesel fuel. Gas chromatography testing method and synchronous fluorescence method are also recommended to check the adulteration of diesel, kerosene and aviation turbine fuel. Four variable equations referred in this paper would really save the cost of CI engine costing more the $\$ 500,000$ for an underdeveloped country like Nepal and also there would no unintended corruption in buying cetane engine. 
ANNEX I

Table 3: Cetane Index Calculation BRJ Group Sample

\begin{tabular}{|c|c|c|c|c|c|c|c|c|c|c|c|}
\hline \multirow{2}{*}{$\begin{array}{l}\text { Sample } \\
\text { Number }\end{array}$} & \multicolumn{3}{|c|}{ Recovery Temperature } & \multicolumn{8}{|c|}{ Estimation of Cetane Index } \\
\hline & $\begin{array}{l}10 \% \mathrm{v} / \mathrm{v} \\
{ }^{0} \mathrm{C}\end{array}$ & $\begin{array}{l}50 \% \mathrm{v} / \mathrm{v} \\
{ }^{0} \mathrm{C}\end{array}$ & $\begin{array}{l}90 \% \mathrm{v} / \mathrm{v} \\
{ }^{0} \mathrm{C}\end{array}$ & $\mathrm{T}_{10} \mathbf{N}$ & $\mathrm{T}_{50} \mathrm{~N}$ & $\mathrm{~T}_{90} \mathrm{~N}$ & DN & A & Exp. & B & CI \\
\hline BRJ 2 & 180 & 264 & 354 & -35 & 4 & 44 & 0.00 & 0.00 & 1.00 & 0.00 & 39.20 \\
\hline BRJ 9 & 167 & 231 & 330 & -48 & -29 & 20 & 0.00 & 0.00 & 1.00 & 0.00 & 33.86 \\
\hline BRJ 24 & 180 & 270 & 354 & -35 & 10 & 44 & 0.00 & 0.00 & 1.00 & 0.00 & 39.98 \\
\hline BRJ 41 & 170 & 205 & 269 & -45 & -55 & -41 & 0.00 & 0.00 & 1.00 & 0.00 & 30.25 \\
\hline BRJ 44 & 176 & 225 & 330 & -39 & -35 & 20 & 0.00 & 0.00 & 1.00 & 0.00 & 34.30 \\
\hline BRJ 20 & 178 & 260 & 350 & -37 & 0 & 40 & 0.00 & 0.00 & 1.00 & 0.00 & 38.56 \\
\hline BRJ 18 & 175 & 246 & 345 & -40 & -14 & 35 & 0.00 & 0.00 & 1.00 & 0.00 & 36.49 \\
\hline BRJ 12 & 179 & 255 & 345 & -36 & -5 & 35 & 0.00 & 0.00 & 1.00 & 0.00 & 38.23 \\
\hline BRJ 13 & 176 & 248 & 348 & -39 & -12 & 38 & 0.00 & 0.00 & 1.00 & 0.00 & 36.79 \\
\hline BRJ 31 & 180 & 253 & 353 & -35 & -7 & 43 & 0.00 & 0.00 & 1.00 & 0.00 & 37.81 \\
\hline BRJ 33 & 178 & 250 & 346 & -37 & -10 & 36 & 0.00 & 0.00 & 1.00 & 0.00 & 37.41 \\
\hline BRJ 1 & 180 & 265 & 350 & -35 & 5 & 40 & 0.00 & 0.00 & 1.00 & 0.00 & 39.49 \\
\hline BRJ 3 & 181 & 270 & 355 & -34 & 10 & 45 & 0.00 & 0.00 & 1.00 & 0.00 & 40.08 \\
\hline BRJ 6 & 178 & 255 & 342 & -37 & -5 & 32 & 0.00 & 0.00 & 1.00 & 0.00 & 38.18 \\
\hline BRJ 7 & 176 & 253 & 345 & -39 & -7 & 35 & 0.00 & 0.00 & 1.00 & 0.00 & 37.55 \\
\hline BRJ 11 & 182 & 262 & 348 & -33 & 2 & 38 & 0.00 & 0.00 & 1.00 & 0.00 & 39.47 \\
\hline BRJ 15 & 181 & 260 & 353 & -34 & 0 & 43 & 0.00 & 0.00 & 1.00 & 0.00 & 38.86 \\
\hline BRJ 16 & 175 & 230 & 337 & -40 & -30 & 27 & 0.00 & 0.00 & 1.00 & 0.00 & 34.65 \\
\hline BRJ 22 & 180 & 260 & 342 & -35 & 0 & 32 & 0.00 & 0.00 & 1.00 & 0.00 & 39.13 \\
\hline BRJ 35 & 180 & 250 & 355 & -35 & -10 & 45 & 0.00 & 0.00 & 1.00 & 0.00 & 37.33 \\
\hline BRJ 28 & 187 & 278 & 355 & -28 & 18 & 45 & 0.00 & 0.00 & 1.00 & 0.00 & 42.02 \\
\hline BRJ 24 & 192 & 275 & 358 & -23 & 15 & 48 & 0.01 & 0.00 & 1.00 & 0.00 & 42.24 \\
\hline BRJ 26 & 182 & 262 & 347 & -33 & 2 & 37 & 0.00 & 0.00 & 1.00 & 0.00 & 39.50 \\
\hline BRJ 37 & 185 & 270 & 360 & -30 & 10 & 50 & 0.00 & 0.00 & 1.00 & 0.00 & 40.44 \\
\hline BRJ 39 & 180 & 245 & 342 & -35 & -15 & 32 & 0.00 & 0.00 & 1.00 & 0.00 & 37.17 \\
\hline BRJ 43 & 185 & 260 & 355 & -30 & 0 & 45 & 0.00 & 0.00 & 1.00 & 0.00 & 39.37 \\
\hline
\end{tabular}

Source: Field survey, ITDG Lab, NOC Lab, NBMS Lab, Soil test Lab, 2002. 
Table 4: Cetane Index Calculation Kathmandu Valley Sample

\begin{tabular}{|c|c|c|c|c|c|c|c|c|c|c|c|}
\hline \multirow{2}{*}{$\begin{array}{l}\text { Sample } \\
\text { Number }\end{array}$} & \multicolumn{3}{|c|}{ Recovery Temperature } & \multicolumn{8}{|c|}{ Estimation of Cetane Index } \\
\hline & $\begin{array}{l}10 \% \mathrm{v} / \mathrm{v} \\
{ }^{\circ} \mathrm{C}\end{array}$ & $\begin{array}{l}50 \% \text { v/v } \\
{ }^{0} \mathrm{C}\end{array}$ & $\begin{array}{l}90 \% \mathrm{v} / \mathrm{v} \\
{ }^{\circ} \mathrm{C}\end{array}$ & $\mathrm{T}_{10} \mathrm{~N}$ & $\mathrm{~T}_{50} \mathrm{~N}$ & $\mathrm{~T}_{90} \mathrm{~N}$ & DN & $\mathbf{A}$ & Exp. & B & CI \\
\hline KTM 6 & 175 & 248 & 255 & -40 & -12 & -55 & 0.00 & 0.00 & 1.00 & 0.00 & 35.87 \\
\hline KTM 24 & 174 & 245 & 250 & -41 & -15 & -60 & 0.00 & 0.00 & 1.00 & 0.00 & 35.06 \\
\hline KTM 34 & 178 & 265 & 348 & -37 & 5 & 38 & 0.00 & 0.00 & 1.00 & 0.00 & 39.28 \\
\hline KTM 58 & 175 & 243 & 330 & -40 & -17 & 20 & 0.00 & 0.00 & 1.00 & 0.00 & 36.51 \\
\hline KTM 65 & 170 & 247 & 335 & -45 & -13 & 25 & 0.00 & 0.00 & 1.00 & 0.00 & 36.24 \\
\hline KTM 67 & 171 & 244 & 340 & -44 & -16 & 30 & 0.00 & 0.00 & 1.00 & 0.00 & 35.85 \\
\hline KTM 69 & 173 & 260 & 255 & -42 & 0 & -55 & 0.00 & 0.00 & 1.00 & 0.00 & 37.17 \\
\hline КTM 92 & 172 & 230 & 320 & -43 & -30 & 10 & 0.00 & 0.00 & 1.00 & 0.00 & 34.56 \\
\hline KTM 8 & 183 & 273 & 355 & -32 & 13 & 45 & 0.00 & 0.00 & 1.00 & 0.00 & 40.76 \\
\hline KTM 18 & 178 & 244 & 342 & -37 & -16 & 32 & 0.00 & 0.00 & 1.00 & 0.00 & 36.74 \\
\hline KTM 30 & 180 & 254 & 340 & -35 & -6 & 30 & 0.00 & 0.00 & 1.00 & 0.00 & 38.40 \\
\hline KTM 48 & 185 & 270 & 355 & -30 & 10 & 45 & 0.00 & 0.00 & 1.00 & 0.00 & 40.67 \\
\hline KTM 50 & 180 & 264 & 350 & -35 & 4 & 40 & 0.00 & 0.00 & 1.00 & 0.00 & 39.37 \\
\hline KTM 54 & 179 & 260 & 350 & -36 & 0 & 40 & 0.00 & 0.00 & 1.00 & 0.00 & 38.70 \\
\hline KTM 56 & 172 & 254 & 345 & -43 & -6 & 35 & 0.00 & 0.00 & 1.00 & 0.00 & 37.13 \\
\hline KTM 74 & 180 & 256 & 349 & -35 & -4 & 39 & 0.00 & 0.00 & 1.00 & 0.00 & 38.36 \\
\hline KTM 76 & 180 & 260 & 352 & -35 & 0 & 42 & 0.00 & 0.00 & 1.00 & 0.00 & 38.76 \\
\hline KTM 4 & 192 & 278 & 362 & -23 & 18 & 52 & 0.01 & 0.00 & 1.00 & 0.00 & 42.44 \\
\hline KTM 10 & 185 & 275 & 355 & -30 & 15 & 45 & 0.00 & 0.00 & 1.00 & 0.00 & 41.32 \\
\hline KTM 2 & 180 & 255 & 354 & -35 & -5 & 44 & 0.00 & 0.00 & 1.00 & 0.00 & 38.03 \\
\hline KTM 14 & 184 & 272 & 355 & -31 & 12 & 45 & 0.00 & 0.00 & 1.00 & 0.00 & 40.78 \\
\hline KTM 12 & 185 & 270 & 353 & -30 & 10 & 43 & 0.00 & 0.00 & 1.00 & 0.00 & 40.75 \\
\hline KTM 16 & 182 & 264 & 352 & -33 & 4 & 42 & 0.00 & 0.00 & 1.00 & 0.00 & 39.57 \\
\hline KTM 20 & 190 & 278 & 353 & -25 & 18 & 43 & 0.00 & 0.00 & 1.00 & 0.00 & 42.56 \\
\hline KTM 22 & 185 & 270 & 355 & -30 & 10 & 45 & 0.00 & 0.00 & 1.00 & 0.00 & 40.67 \\
\hline KTM 26 & 180 & 262 & 345 & -35 & 2 & 35 & 0.00 & 0.00 & 1.00 & 0.00 & 39.29 \\
\hline KTM 32 & 178 & 235 & 337 & -37 & -25 & 27 & 0.00 & 0.00 & 1.00 & 0.00 & 35.72 \\
\hline KTM 36 & 184 & 278 & 357 & -31 & 18 & 47 & 0.01 & 0.00 & 1.00 & 0.00 & 41.47 \\
\hline KTM 38 & 185 & 275 & 355 & -30 & 15 & 45 & 0.00 & 0.00 & 1.00 & 0.00 & 41.32 \\
\hline
\end{tabular}

Source: Field survey, ITDG Lab, NOC Lab, NBMS Lab, Soil test Lab, 2002. 
Table 4: Cetane Index continue...

\begin{tabular}{|c|c|c|c|c|c|c|c|c|c|c|c|}
\hline \multirow{2}{*}{$\begin{array}{l}\text { Sample } \\
\text { Number }\end{array}$} & \multicolumn{3}{|c|}{ Recovery Temperature } & \multicolumn{8}{|c|}{ Estimation of Cetane Index } \\
\hline & $\begin{array}{l}10 \% \mathrm{v} / \mathrm{v} \\
{ }^{0} \mathrm{C}\end{array}$ & $\begin{array}{l}50 \% \mathrm{v} / \mathrm{v} \\
{ }^{0} \mathrm{C}\end{array}$ & $\begin{array}{l}90 \% \mathrm{v} / \mathrm{v} \\
{ }^{0} \mathrm{C}\end{array}$ & $\mathrm{T}_{10} \mathrm{~N}$ & $\mathrm{~T}_{50} \mathrm{~N}$ & $\mathrm{~T}_{90} \mathrm{~N}$ & $\mathrm{DN}$ & A & Exp. & B & CI \\
\hline KTM 42 & 180 & 265 & 348 & -35 & 5 & 38 & 0.00 & 0.00 & 1.00 & 0.00 & 39.57 \\
\hline KTM 44 & 185 & 270 & 360 & -30 & 10 & 50 & 0.00 & 0.00 & 1.00 & 0.00 & 40.44 \\
\hline KTM 46 & 184 & 284 & 355 & -31 & 24 & 45 & 0.00 & 0.00 & 1.00 & 0.00 & 42.35 \\
\hline KTM 52 & 185 & 260 & 348 & -30 & 0 & 38 & 0.00 & 0.00 & 1.00 & 0.00 & 39.65 \\
\hline KTM 63 & 184 & 278 & 352 & -31 & 18 & 42 & 0.00 & 0.00 & 1.00 & 0.00 & 41.70 \\
\hline KTM 71 & 180 & 248 & 344 & -35 & -12 & 34 & 0.00 & 0.00 & 1.00 & 0.00 & 37.50 \\
\hline KTM 72 & 183 & 260 & 350 & -32 & 0 & 40 & 0.00 & 0.00 & 1.00 & 0.00 & 39.28 \\
\hline KTM 78 & 178 & 255 & 350 & -37 & -5 & 40 & 0.00 & 0.00 & 1.00 & 0.00 & 37.91 \\
\hline КTM 79 & 179 & 256 & 345 & -36 & -4 & 35 & 0.00 & 0.00 & 1.00 & 0.00 & 38.37 \\
\hline KTM 80 & 180 & 255 & 352 & -35 & -5 & 42 & 0.00 & 0.00 & 1.00 & 0.00 & 38.11 \\
\hline KTM 84 & 178 & 255 & 346 & -37 & -5 & 36 & 0.00 & 0.00 & 1.00 & 0.00 & 38.05 \\
\hline KTM 86 & 176 & 252 & 343 & -39 & -8 & 33 & 0.00 & 0.00 & 1.00 & 0.00 & 37.48 \\
\hline KTM 88 & 178 & 254 & 345 & -37 & -6 & 35 & 0.00 & 0.00 & 1.00 & 0.00 & 37.96 \\
\hline KTM 90 & 175 & 210 & 293 & -40 & -50 & -17 & 0.00 & 0.00 & 1.00 & 0.00 & 32.26 \\
\hline KTM 91 & 178 & 215 & 330 & -37 & -45 & 20 & 0.00 & 0.00 & 1.00 & 0.00 & 33.28 \\
\hline KTM 93 & 176 & 235 & 330 & -39 & -25 & 20 & 0.00 & 0.00 & 1.00 & 0.00 & 35.60 \\
\hline KTM 61 & 180 & 260 & 348 & -35 & 0 & 38 & 0.00 & 0.00 & 1.00 & 0.00 & 38.92 \\
\hline KTM 28 & 178 & 275 & 350 & -37 & 15 & 40 & 0.00 & 0.00 & 1.00 & 0.00 & 40.52 \\
\hline KTM 44 & 184 & 266 & 351 & -31 & 6 & 41 & 0.00 & 0.00 & 1.00 & 0.00 & 40.16 \\
\hline
\end{tabular}

Source: Field survey, ITDG Lab, NOC Lab, NBMS Lab, Soil test Lab, 2002. 


\section{References}

Ale, B. B. (2003). Fuel adulteration and tailpipe emissions. Journal of Institute of Engineering, Department of Mechanical Engineering, Pulchowk Campus, Institute of Engineering,3 (1), 12-16.

Alliance of Automobile Manufactors. (2005). Worldwide fuel charter. Washington DC: Author.

ASTM D4737-09 (2009). Standard test method for calculated cetane index by four variable equation. ASTM International, West Conshohocken, PA. Retrieved fromwww. astm.org, DOI: 10.1520/D4737-09.

Cataluna,R., \& Silva,R. D. (2012).Effect of cetane number on specific fuel consumption and particulate matter and unburned hydrocarbon emissions from diesel engines. Journal of Combustion, Hindawi Publishing Corporation, 2012 (1-6). Retrievedfromhttp://dx.doi.org/10.1155/2012/738940.

Daniel, S.B.(2003). Abatement airquality monitoring of Kathmandu valley:Implementating the outcomes of the world subimation sustainable development. Nepall Environmental and Scientific Services Pvt. Ltd.Photonics Technology World, USA.

Dooley, S., Won, S. H., Heyne, J., Farouk, T. I., Ju, Y., Dryer, F. L., ...Brezinsky, K. (2012). The experimental evaluation of a methodology for surrogate fuel formulation to emulate gas phase combustion kinetic phenomena. Combustion and Flame, 159, 1444-1466. Retrievedfrom https://doi:10.1016/j. combustflame.2011.11.002.

Environment Australia. (2002). Setting national fuel quality standard part 2: Standards for fuel parameters (petrol and diesel).Canberra Publishing Co Pty Ltd., (CPP), Instant Pritinf Australia.

Faiz, A., Weaver, C. S., \& Walsh, M. P. (1996). Air pollution from moter vehicles:Standards and technologies for controlling emisions. Washington DC:The World Bank.

Giri, D., Murt, V. K., Adhikary, P. R., \& Khanal, S. N. (2007). Estimation of number of deaths associated with exposure to excess ambient $\mathrm{PM}_{10}$ air pollution. International Journal of Environmental Science and Studies, 4 (2), 183-188.

Gupta, S. B. (2004). Transport fuel adulteration. Central Pollution Control Board, Delhi32.

Gupta, U. (2005). Valuation of urban air pollution: A case study of Kanpur Nagar. South Asian Network for Development and Ebnviromental Economics (SANDEE).

Helga G. A., \& Paulo, J. S. B. (2012). Determination of flash point and cetane index in diesel using distillation curves and multivariate calibration. Fuel. Science 
Direct 129-134.Retrievedfromjournal homepage: www.elsevier.com/locate/ fuel.

Hill, J. W. (2000). Chemistry for changing times (7th 95-old ed.). USA: In service Oil Analysis Program Irving Lubricant Division .

Intermediate Technological Development Group(ITDG).(2002). Abatement measures on vehicular air polution in Kathmandu valley, Draft Report. Kathmandu, Nepal: Author.

Joshua, S. H., Andre, L. B., \& Steven, K. (2009). Autoignition studies of trans- and cisDecalin in an ignition quality tester (IQT) and the development of a high thermal stability unifuel/single battlefield fuel. Energy Fuels. The EMS Energy Institute, the Pennsylvania State University, 23, 5879-5885. Retrievedfrom https://doi:10.1021/ef900715m.

Ken, G., Masami, K., \& Todd, J. (2004). Reducing air pollution from urban transport. Washington, D.C:The World Bank.

Khadka, C. B. (2007). Health impact of tailpipe emissions in Kathgmandu Valley, Nepal. Economic Journal of Development Issues, 8 (1 \& 2), 67-87.

Khadka, C. B. (2010). Economic impact analysis of petroleum adulteration in Nepal (Unpublished PhD Dissertation). Faculty of Humanities and Social Sciences of Tribhuvan University, Kirtipur, Nepal.

Lal, A. K., \& Clement, R. W. (2005). Economic development in India: The role of individual enterprise (and entrepreneurial spirit). Asia-Pacific Development Journal, 12 (2), 81-99. Retrievedfromhttps://pdfs.semanticscholar.org/4954/2c1 e441bf43d3d76736d33083b2071212fe0.pdf.

Masami, K. (2003). Urban air quality management transpor-environment-energy nexus. Washington DC: Oil Gas and Chemicals Department the World Bank.

Mishra, N., Chawala, R., Srivastava, L., \& Pachauri,R. K. (2005). Petroleum pricing in India: Balancing efficiency and eqity. Darbari Seth Block IHC Complex Lodhi Road New, Delhi India: The energy and Resources Institute .

The National Energy Technology Laboratory. (2008). Can alternative energy effectively replace fossil fuels? Department of Energy NETL supports DOE's mission to advance the national, economic, and energy security of the United States Washington D. C.

National Fuel Quality Standards.(2004). Measuring cetane number: Options for diesel and alternative diesel fuels. The Department of the Environmrnt and Heritage, Australian Government. Author 
Rom \& Hass Co. (1982). V. Adco. Chem.Co.Retrievedfrom https:// 689F2d,424,429 UK 93d Cir.

Romanini, D. C., Trindade, M. A. G., \& Zanoni, M. V. B. (2009). A simple electroanalytical method for the analysis of the dye solvent orange 7 in fuel ethanol. Fuel, 88,105109.Retrievedfrom https://doi: 10.1016/j.fuel.2008.07.022.

Taksande, A., \& Hariharan, C. (2014). Synchronous fluorescence method to check adulteration of petrol and diesel by kerosene.An International Journal for Rapid Communication, 13, 345-356.Retrievedfromhttp://www.tandfonline.com/loi/ 1 st120.

United States Environmental Protection Agency. (2002). Method forcalculating cetane index of diesel fuels. National vehicle and fuel emissions laboratory. USA. Author. http://www.cnama.org/wp-content/uploads/2009/11/121.pdf.

William, E. F. (1946). Smiths general chemistry colleges (6 $6^{\text {th }}$ ed.). London: G. Bell and Sons Ltd.

World Bank. (1998). Pollution prevention and abaterment handbook. Washington DC: Author.

(2000). Environmental costs of fossil fuels: A rapid assessment method with application to six cities. Washington DC: Author.

. (2001).Cleaner transport fuels for cleaner air in Central Asia and the Caucasus Report.Washington, DC: Author.

. (2002a). Catching gasoline and diesel adulteration. Washington DC: Author.

.(2002b). Improving air quality in metropolitan Mexico city: An economic valuation. Washington DC: Author.

.(2003a). Urban air pollution, economic valuation of the health benefits of reduction in air pollution. Washington DC: Author

. (2003b).Health impacts of outdoor air pollution:Urban air pollution(South Asia urban air quality management briefing note No .1).Washington,DC: Author

. (2007). Cost of air pollution in China: Economic estimates of physical damages. Washington DC: Author. 